\title{
THE VALUE OF GYNAECOLOGICAL EXAMINATIONS IN SPINAL CORD INJURED WOMEN
}

\author{
By A. T. Terbizan, M.D. ${ }^{1}$ and W. D. Schneeweiss, M.D. ${ }^{2}$ \\ Rehabilitation Centre, Tobelbad/Graz der Auva, Austria, Universitätsfrauenklinik, \\ Graz-Austria
}

Summary. The necessity for regular gynaecological examinations in tetraparaplegic and paraplegic women is pointed out. Outcomes of such examinations during a two and a half year period in the Rehabilitation Centre of Tobelbad illustrate this, as is shown in the tables.

Key words: Spinal paralysed women; Gynaecological investigations and findings.

AfTER discharge from the Spinal Centre, many, if not most, spinal cord injured women are faced with problems concerning gynaecological examinations. One of the problems is the long distance between her home and the place for the gynaecological examination; and also the consulting room usually has architectural obstacles.

The incomplete or complete loss of sensibility increases the morbidity rate of inflammations in the genital regions of paralysed women. Gynaecological disorders may include simple colpitis with vaginal discharge, as well as severe, acute or chronic inflammation of the fallopian tubes and the ovaries.

Menstrual disorders such as amenorrhea, dysmenorrhea and metrorrhagia demand a clinical analysis, and if necessary, treatment similar to that for non-paralysed women.

Even without any symptom, the possibility of uterine cancer demands a yearly gynaecological check up. Statistics from Europe and America show that breast cancer is the most frequent malignant tumour in women. In Germany three to four women per hundred are affected with such a malignancy. Breast and genital carcinomas together account for up to 50 per cent of all malignant growths. In the genital region cervical cancer is the commonest ( 50 per cent), followed by carcinoma of the corpus uteri (20 per cent). Next are the heterogeneus group of ovarian tumours with an incidence of 15 per cent. The incidence of cancer of the vulva is about 5 per cent. Primary carcinoma of the fallopian tubes and vagina are very rare.

For these reasons we began to carry out regular gynaecological studies once a year in our centres. Before these, routine check-ups; paralysed women were only examined after requesting to be seen by a gynaecologist.

The gynaecologist involved is a consultant in the University Clinic for Obstretics and Gynaecology in Graz, and co-operates closely with the spinal rehabilitation centre. We distinguish between two kinds of gynaecological studies; the first takes place shortly after admission to the centre and is intended to obtain a gynaecological status. The second examination is a follow up, which is combined with a routine urological check-up.

The parameters of gynaecological explorations are: Inspection and palpation of the breasts, colposcopy and cytology for early uterine cancer 
detection, and a bimanual vaginal and rectal study. In extremely obese patients, women with severe spasticity or patients suffering from autonomic hyper-reflexia the exploration is carried out under a general anaesthetic.

Surgical treatment can take place in the rehabilitation centre for minor operations such as removal of cervical polyps followed by a cervical canal curettage. There is no doubt that the pre- and post-operative care of the patient is best carried out at the Centre, because well trained doctors and well educated nursing staff are available. Major operations such as vaginal hysterectomy or perineal repair for stress incontinence caused by vaginal prolapse are carried out in the University Clinic of Obstretics and Gynaecology in Graz. After operation, patients when fit enough are transferred back to the spinal unit.

The results of our gynaecological examinations, covering a period of two and a half years (I October I979-3 I March I982) are now given.

\section{TABLE I}

Patients' age, and frequency of gynaecological examinations

\begin{tabular}{|c|c|c|c|}
\hline \multicolumn{2}{|l|}{ Age } & \multicolumn{2}{|l|}{$\begin{array}{l}\text { Frequency of gynaecological examinations before being } \\
\text { seen at the centre }\end{array}$} \\
\hline I $5-30$ & $2 \mathrm{I}$ & Not previously examined & I7 \\
\hline $3 I-50$ & 32 & Regular check-up before seen at the & \\
\hline $5 I-70$ & 43 & centre & 20 \\
\hline over 70 & 6 & Occasional check-up & 30 \\
\hline & & $\begin{array}{l}\text { Failure to attend for examination after the onset } \\
\text { of paralysis }\end{array}$ & \\
\hline & & No comment & 30 \\
\hline
\end{tabular}

Table I shows the distribution of age. The onset of the paralysis from an accident or from functional disease varied from I month to 3 I years. Eight-one patients had an accident, 2 I patients were suffering from a medical disease. One hundred and two patients underwent 133 explorations. The frequency of examination per patient in the centre was I-5 times. Only six of 20 patients were paralysed for more than I year.

TABLE II

The incidence of gynaecological abnormalities

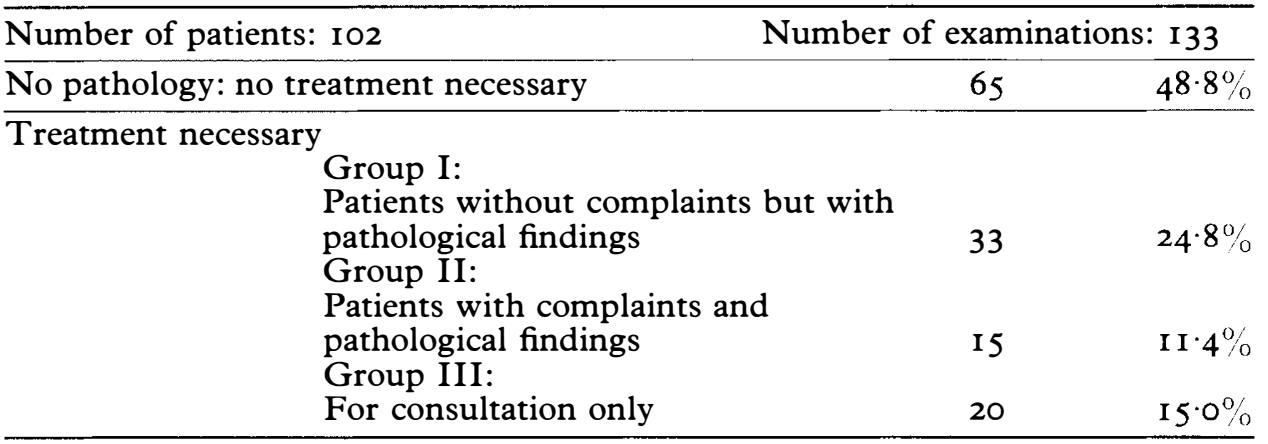


Table II gives the incidence of gynaecological abnormalities in 133 examinations. Four of the 65 patients had examinations under general anaesthesia.

Table III shows the diagnosis in group one to three of Table II.

Table IV sets out the types of operations performed.

TABLE III

The diagnosis in group I, 2 and 3

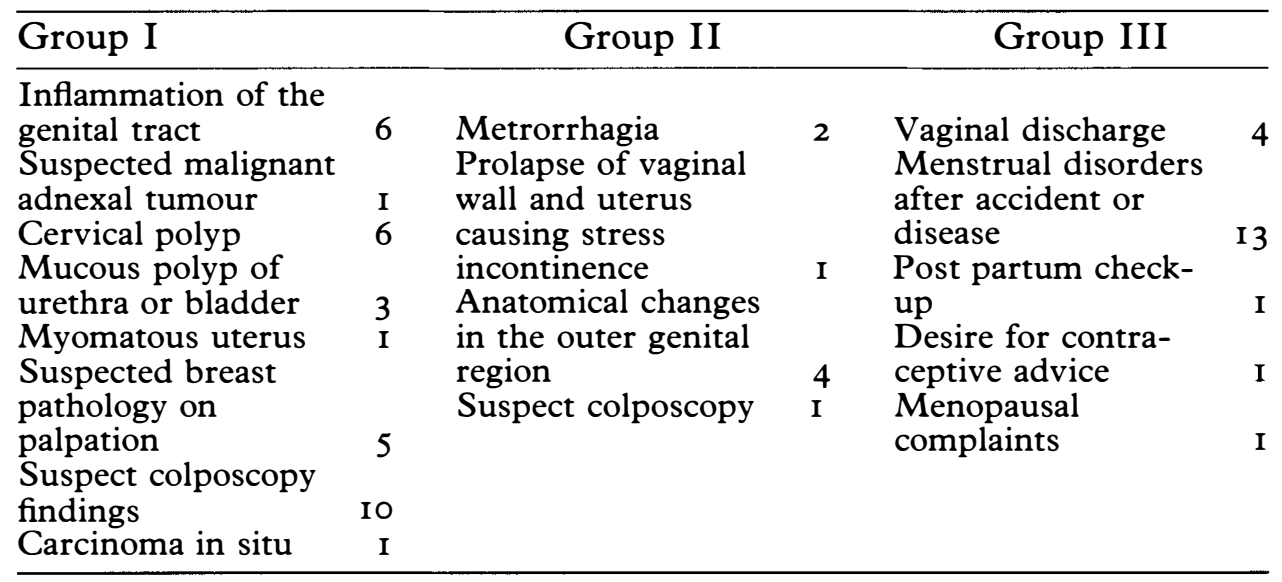

TABLE IV

Operations performed

\begin{tabular}{|c|c|c|c|c|c|}
\hline At centre & & At clinic & & $\begin{array}{c}\text { Treatment as an } \\
\text { outpatient }\end{array}$ & \\
\hline $\begin{array}{l}\text { Scotts conisation } \\
\text { Electrical conisation } \\
\text { Dilation and } \\
\text { curretage } \\
\text { Exploration under } \\
\text { general anaesthesia } \\
\text { Marsupialisation } \\
\text { Plastic grafts in outer } \\
\text { genital region }\end{array}$ & $\begin{array}{l}3 \\
4 \\
\text { I } \\
3\end{array}$ & $\begin{array}{l}\text { Mastectomy } \\
\text { Vaginal hysterectomy } \\
\text { with perineal repair } \\
\text { Abdominal } \\
\text { hysterectomy } \\
\text { Prenatal supervision } \\
\text { and delivery by } \\
\text { caesarian section }\end{array}$ & & $\begin{array}{l}\text { Cervical biopsy } \\
\text { Removal of cervical } \\
\text { polyp by cervical } \\
\text { currettage }\end{array}$ & I I \\
\hline
\end{tabular}

\section{Conclusions}

This paper shows the value and the striking results of regular gyneacological examinations in a spinal rehabilitation centre. There should be proper arrangements for paralysed women to have a gynaecological examination at least once a year, shown by the fact that $5 \mathrm{I} \cdot 2$ per cent of our explored patients required treatment, and 24.8 per cent had no clinical symptoms or discomfort because of their spinal disorder. In the group with no complaints, two patients had a carcinoma, cervical in one and breast in one. Complete cure was possible by a minor operation in the case of 
the patient with cervical cancer because of the early detection. The value of gynaecological examinations in paraplegic women is obvious for two reasons: Although gynaecological disorders are not significantly more common in spinal paralysed women than in non-spinal paralysed, it is the loss of sensibility which increases the risk of disregarding gynaecological disorders. The paralysed women have no complaints therefore they do no consult a gynaecologist. Another problem is that paralysed women are unable to continue with their routine gynaecological check-ups that they had before the onset of their paralysis because of the lack of adequate facilties for examining paralysed women. Therefore, spinal rehabilitation centres should be well equipped for such complex gynaecological examinations.

\section{RÉSUMÉ}

On attache beaucoup dimportance á une réguliére examination gynécologiques des tétraparaplégiques. Sous forms de tableaux on démontre les explications detaillees des exploration gynécologiques durant deux annees et demi au Rehabilitations-Centre Tobelbad.

\section{ZUSAMMENFASSUNG}

Auf die Wichtigkeit einer regelmässigen gynäkologischen Untersuchung bei tetra- und paraplegische Frauen wird referiert. Ergebnisse und Aufschlüsselung der gynäkologischen Explorationen über sweieinhalb Jahren im RZ Tobelbad werden an Hand von Tabellen aufgezeigt.

\section{REFERENCES}

Bors, E. \& Harris, P. (1963). Proc. Symp. Spinal Injuries, pp. 62-70. Royal College of Surgery, Edinburgh.

CARrIE, L. E. S. (I977). Conduction Analgesia, in: Stallworthy, I. and Burns, G. (eds) Recent Advances in Obstretics and Gynaecology. Edinburgh: Churchill Livingstone.

FitzPatrick, W. F. (1974). Sexual function in paraplegic patient. Archs Phys. Med. Rehab., 55,22 I-227.

GutTMANN, L. (1973). Spinal Cord Injuries, chapt. 28. Oxford: Blackwell.

Rossier, A. B., Ziegler, W. H., Duchosal, A. \& MAYlan, J. (I97I). Sexual function and dysreflexia. Paraplegia, 9, 5 I-59.

TALbOT, H. S. (1955). Sexual function in paraplegia. F. Urol., 73, 91-100. 